\title{
POLICY Health and care spending and its value, past, present and future
}

\author{
Authors: Toby Watt, ${ }^{A}$ Anita Charlesworth ${ }^{\mathrm{B}}$ and Ben Gershlick ${ }^{\mathrm{C}}$
}

In times of relatively low public spending in the UK since 2009-2010, health spending has been protected above all else. At the same time budgets for education, housing and public safety have fallen. This is in part due to the presence of growing demand for healthcare: while the population has increased by around one-third since 1950, healthcare spending as a share on national income has more than doubled.

Continuing increases in quantity and complexity of the use of the health service as well as the unit costs indicate that these pressures will not be alleviated any time soon. However, there are clear benefits to investing in health; research finds that a $10 \%$ increase in health spending was associated with a gain of 3.5 months of life expectancy across the Organisation for Economic Co-operation and Development from 1995 to 2015. In this paper, we discuss the potential value of additional spending.

KEYWORDS: Health and care spending, healthcare demand, value

\section{Introduction}

Health and social care delivery in the UK is complex; balancing quality of care, universal coverage, equality of access, efficiency and growing healthcare demands. Finding this balance necessitates equally complex policy decisions and, in times of austere public finance, these decisions are profoundly challenging. Healthcare has been largely free at the point of use in the UK since 1948. In that time both the service and the population have changed substantially: annual spending has increased ten-fold; care has shifted towards long-term management of chronic illness; as treatments have improved, both life expectancy and healthy life expectancy have risen. ${ }^{1}$ The NHS workforce has grown from around 144,000 in 1948 to more than 1.2 million full-time equivalent employees today. ${ }^{2}$

Social care in England is very different. Social care services are means tested, not free at the point of use and while spending has grown over the decades there is a growing gap between pressures

Authors: A senior economist, The Health Foundation, London, UK; ${ }^{B}$ director of research and economics, The Health Foundation,

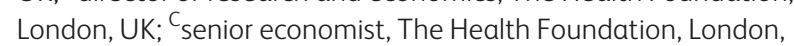
UK on the system and the funding available. ${ }^{3}$ Spending on social care in England has fallen by $11 \%$ from $2009 / 10$ to $2015 / 16$. While other devolved nations have held or increased their spending on social care, the government in England has frozen the means tested thresholds in nominal terms, reduced funding and access for those with limited financial resources, thereby shifting more of the cost of social care on to the individual. ${ }^{4}$

In this paper we discuss how health and care has changed over time, how the UK compares internationally, the future pressures on the system and the potential value of additional spending.

\section{Healthcare is changing}

Publicly funded healthcare spending in the UK has grown almost every year since the NHS's inception. Over the last 70 years, the number and type of patients the NHS cares for have changed, as well as the way that it delivers care. Public spending has increased more than 10 -fold in real terms, by an average of $3.7 \%$ a year, but also relative to other areas of public and private spending. ${ }^{5}$ As a share of national income, spending on publicly funded healthcare has doubled from 3.5 to $7.3 \%$, while the population has increased by around a third since $1950 .^{5}$

\section{Demographic pressures}

The UK has a growing and ageing population, both of which are related to higher demand for healthcare (Table 1). The impact of population ageing on healthcare costs is illustrated in Fig 1, the average UK public spending on health (relative to a 30 -year-old). ${ }^{6}$

Table 1. UK population size and age composition

\begin{tabular}{lllllllll} 
& \multicolumn{3}{c}{$\begin{array}{c}\text { Population size } \\
\text { (millions) }\end{array}$} & & \multicolumn{3}{c}{$\begin{array}{c}\text { Proportion of total } \\
\text { population (\%) }\end{array}$} \\
\cline { 2 - 4 } Year & $\mathbf{1 9 5 3}$ & $\mathbf{1 9 8 5}$ & $\mathbf{2 0 1 6}$ & & $\mathbf{1 9 5 3}$ & $\mathbf{1 9 8 5}$ & $\mathbf{2 0 1 6}$ \\
Total & 50.6 & 56.6 & 65.6 & & 100.0 & 100.0 & 100.0 \\
$0-14$ & 11.5 & 10.9 & 11.7 & & 22.8 & 19.2 & 17.8 \\
$15-39$ & 17.3 & 21.2 & 21.1 & & 34.2 & 37.6 & 32.2 \\
$40-64$ & 16.1 & 15.9 & 21 & & 31.9 & 28.0 & 32.0 \\
$65-84$ & 5.4 & 7.9 & 10.2 & & 10.6 & 13.9 & 15.6 \\
$85+$ & 0.2 & 0.7 & 1.6 & & 0.5 & 1.2 & 2.4 \\
\hline
\end{tabular}

Adapted with permission from Office for National Statistics. Population in England by age 2011 to 2017. ONS, 2017. 
Fig 1. Age profile of UK public spending on health (relative to 30 -year-old). Adapted with permission from Office for Budget Responsibility. Fiscal sustainability report - January 2017. Office for Budget Responsibility: London, 2017.

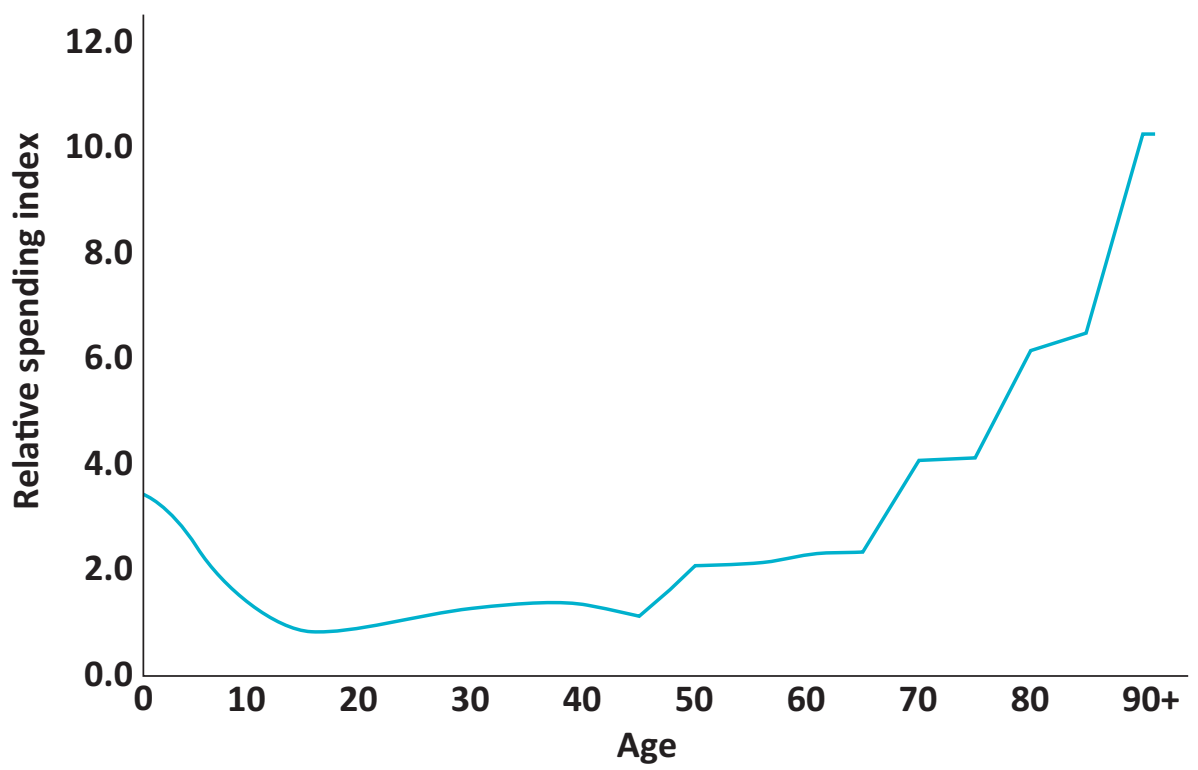

Between 2009/10 and 2019/20, population growth and ageing alone causes demand pressures of $1.3 \%$ per year on health spending. ${ }^{7}$ In addition, ageing puts greater pressure on the adult social care system, which requires growth of $3.7 \%$ per year to maintain the current system in 2030/31. ${ }^{3}$

The health and care impact of population ageing, depends on the proportion of life expectancy spent in good or ill health.

> Compression of morbidity occurs when individuals who are expected to live longer, spend the same amount of time (or less) in ill health. This could be driven by better population health leading to lower incidence of chronic conditions.

$>$ Expansion of morbidity occurs when rising life expectancy is not matched by improvements in morbidity with more time spent in ill health.

\section{Population health}

In recent years, there has been an increasing prevalence of chronic conditions, as a result of higher prevalence of lifestyle risk factors such as obesity; ${ }^{8}$ an increasing life expectancy has allowed more time for the population to develop chronic conditions in older age. This rising prevalence is impacting on acute healthcare. Fig 2 shows how the rate of people over 65 admitted to hospital with a chronic condition has increased by $60 \%$, for multiple conditions admission rates have more than doubled. A recent study found that one in four adults had two or more health conditions. ${ }^{9}$ This equates to approximately 14.2 million people in England with multiple conditions from 2014-2016.

\section{Non-demographic demand pressures}

Over the last 70 years, health spending patterns and demand are not explained purely by changing patterns of population growth, ageing, mortality and morbidity. Patterns of demand are influenced by public expectations; preferences for improvements in healthcare compared to other possible uses of public and private spending. As societies get richer, research suggests they prioritise part of that growing income and wealth for healthcare. This is known as the income elasticity of demand for healthcare. Research is inconclusive on the precise value of income elasticity with respect to healthcare. If health spending grows proportionally faster (income elasticity of greater than one) is unclear, but all research does find that income elasticity is positive. ${ }^{10,11}$ This preference for healthcare and changing expectations are also influenced by what is technologically possible and what is available.

\section{Cost pressures and productivity}

NHS spending growth is also influenced by real terms increases in unit costs. Over $60 \%$ of NHS costs are staff, whose wages grew by around $2 \%$ a year in real terms in the 35 years up to $2009 / 10 .^{12}$ These wage increases have outpaced healthcare productivity, which has grown by $0.7 \%$ a year in the UK from 2000 to 2009 , going against classical economic theory that real wages should be tied to labour productivity.

These rising labour costs occur because of labour productivity in other sectors leads to higher wages in those sectors. The health service is therefore required to increase pay to compete in the labour market and maintain a highly skilled workforce. ${ }^{13}$ Staff pay increases have been much lower in the period of austerity since 2009 , with pay for most staff groups capped or frozen since $2010 / 11$. In this period, cost pressures have reduced and average productivity has necessarily increased to $1.7 \%$ per year, above the long-term average. ${ }^{14}$ However, this may have been a contributor to the current staff shortages and is not a sustainable option for alleviating cost pressures in the long term. ${ }^{15}$

\section{International health spending}

The fundamental drivers of health spending are the same across the industrialised world, most countries have seen health 


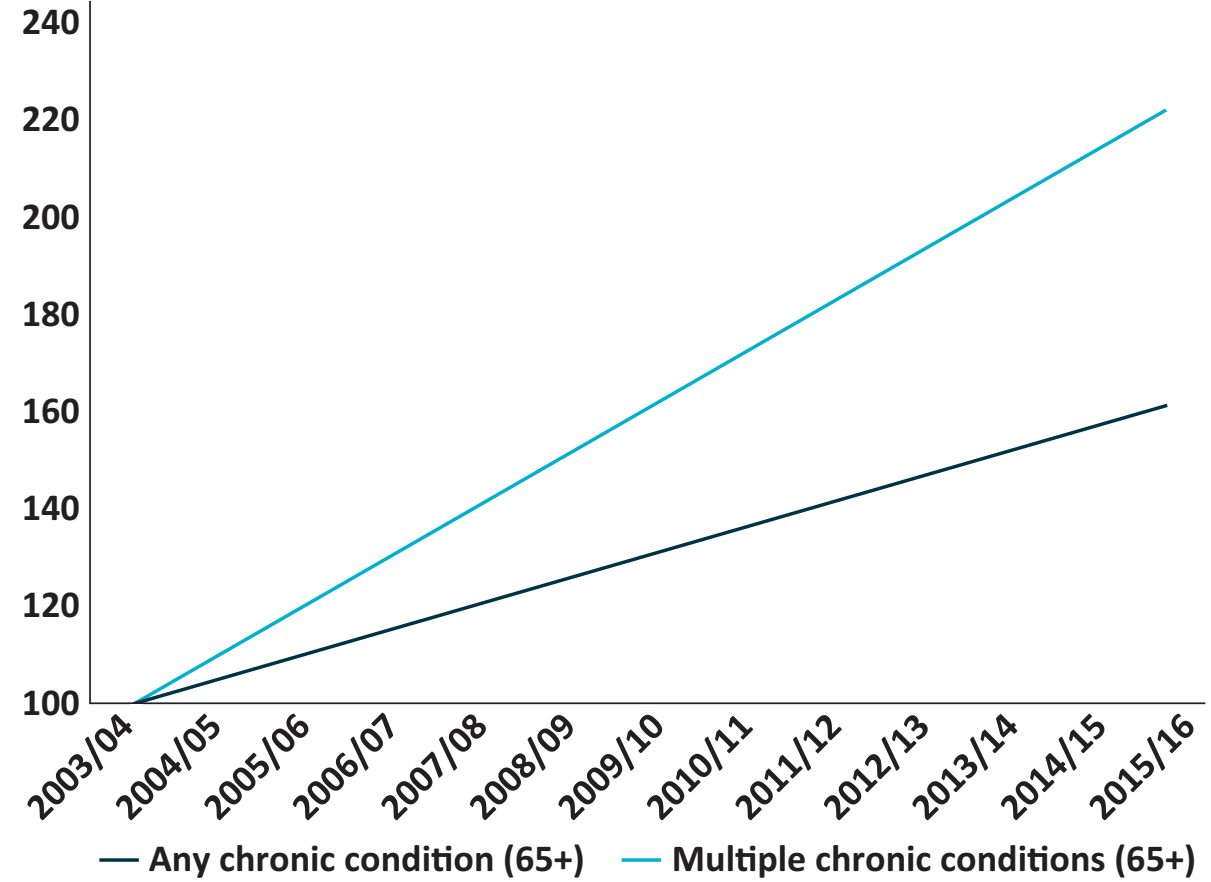

Fig 2. Growth in chronic conditions identified in inpatient Hospital Episode Statistics ( 65 and over). Calculated from Hospital Episode Statistics data

spending grow by more than inflation and economic growth in the last century and expect to continue in this century. One projection has spending on health and long-term care growing on average among the Organisation for Economic Co-operation and Development (OECD) countries (a collection of 36 countries) by between 3.3 and 7.7 percentage points of gross domestic product (GDP) between 2010 and 2060, depending on the extent to which countries are able to contain costs. ${ }^{11}$

Total health spending (public and private), based on a definition of health which includes much of social care, for the UK is around $£ 1$ in $£ 10$ of GDP. In 2016, UK health spending was $9.8 \%$ of GDP, higher than the OECD average of $8.9 \%$ and roughly in-line with the EU-14 (first 15 countries to join the EU, minus the UK) average of $9.5 \%$ (Fig 3). There is relatively little variation between EU-14 countries, Luxembourg has the lowest share of GDP devoted to healthcare (largely due to its unusually strong economy with high absolute spending per person) spending $6.2 \%$ of GDP, while France devotes $11.5 \%$ of GDP to healthcare.

Around $80 \%$ of spending in the UK is publicly funded, similar to the EU-14 average of $77 \%$ (OECD health data; refers to government and compulsory health schemes). Private spending is a mix of private health insurance and out-of-pocket payments. The NHS performs well internationally in relation to catastrophic care costs with very few people reporting problems with the cost of healthcare or skipping appointments due to cost. ${ }^{16}$ The World Bank reports that in the UK just $1.6 \%$ of the population spend more than a tenth of their income on the out-of-pocket costs of health problems, compared $7.0 \%$ of the European population as a whole. ${ }^{17}$

In terms of absolute spending, when adjusted for different spending power in different countries, the UK spends around $8 \%$ less per person than the EU-14 average (this divergence being explained by UK GDP per person below the average), but a similar amount $(7 \%)$ above the OECD average.

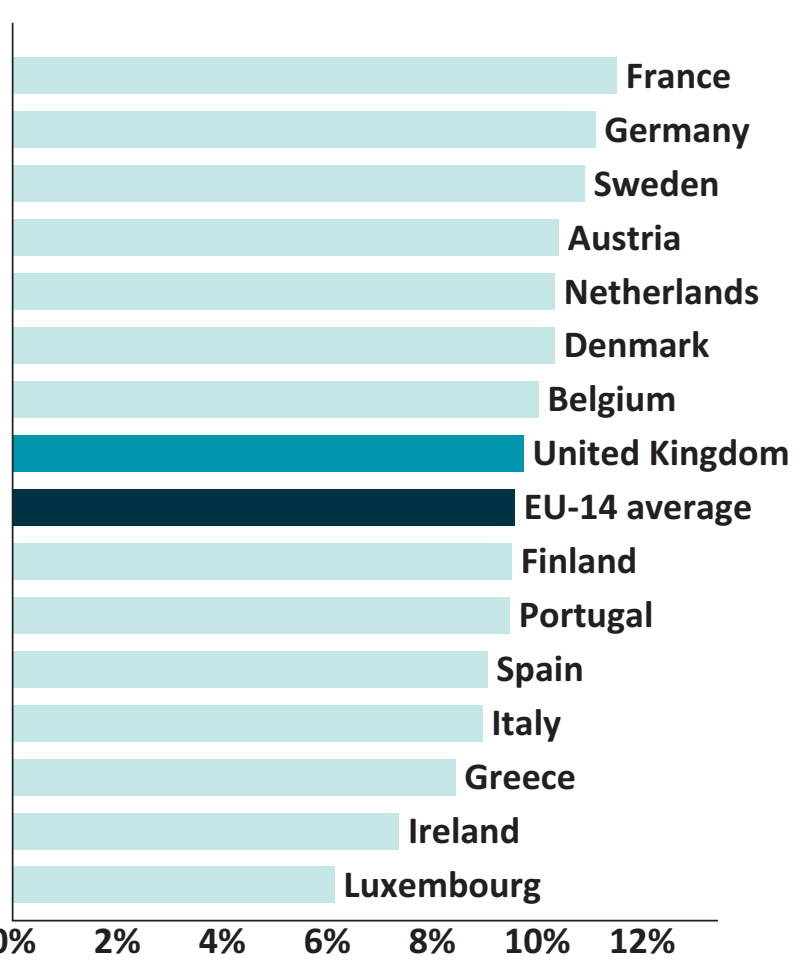

Fig 3. Per cent of gross domestic product spent on healthcare, EU 14 countries in 2016. Calculated from Organisation for Economic Co-operation and Development data. 
Table 2. Ranking of countries by percentage of total health spending allocated to different care settings in 15 EU countries, 2016

\begin{tabular}{lllll} 
Ranking & Inpatient, country (\%) & Outpatient, country (\%) & Day case, country (\%) & Home-based, country (\%) \\
1 & Greece (40.9) & Portugal (40.1) & Portugal (8.4) & France (3.6) \\
2 & Austria (33.0) & Finland (32.2) & Ireland (6.9) & Ireland (3.2) \\
3 & Belgium (29) & Spain (31.0) & Netherlands (5.2) & UK (2.7) \\
4 & Italy (27.9) & Sweden (29.8) & UK (5.0) & Belgium (1.3) \\
5 & France (27.9) & Denmark (29.5) & Italy (4.1) & Netherlands (0.9) \\
6 & Germany (27.3) & Netherlands (27.6) & France (4.0) & Spain (0.8) \\
7 & Denmark (26.3) & UK (26.0) & Luxembourg (3.3) & Finland (0.8) \\
8 & Luxembourg (25.1) & Austria (25.1) & Spain (2.1) & Germany (0.6) \\
9 & Ireland (24.7) & Luxembourg (24.7) & Finland (1.9) & Sweden (0.5) \\
10 & Spain (24.0) & Italy (22.8) & Sweden (1.9) & Portugal (0.4) \\
11 & UK (23.5) & Germany (22.4) & Belgium (1.5) & Italy (0.3) \\
12 & Finland (23.3) & Ireland (19.5) & Germany (1.0) & Luxembourg (0.2) \\
13 & Sweden (20.1) & Belgium (18.6) & Austria (0.9) & Austria (0.1) \\
14 & Netherlands (18.8) & Greece (18.4) & Greece (0.9) & Denmark (NA) \\
15 & Portugal (17.4) & France (17.9) & Denmark (NA) & Greece (NA) \\
\hline NA No data available. & & &
\end{tabular}

This definition of 'health spending' includes much of what we would call social care. While this means the definition goes beyond how we define the 'NHS' in the UK, it may better reflect what we think of as spending on 'health'.18

Much of the remaining social care spending is also captured by the separate category of social long-term care spending which is another $0.6 \%$ of GDP - half of which is public spending and half private. This is higher than the OECD average of $0.4 \%$ and roughly the same as Sweden and France but half that of the Netherlands. Much of this will be driven by the different ways social care is funded and organised.

The majority of high income European countries finance their health system through either a general taxation-based 'Beveridge' model (UK) or social health insurance 'Bismarckian' model which involves specific taxes collected from those in employment, usually allowing access to different insurers (France or Germany). The evidence suggests that neither system strictly dominates another in terms of outcomes or efficiency. ${ }^{19,20}$

Different healthcare systems are also organised differently, which can impact how efficiently they are able to provide care. As a way of making systems more efficient and person-centred, the OECD has encouraged a de-escalation and shift to less intensive care settings - from inpatient to outpatient, to day-case and to home-based care. ${ }^{21,22}$ Along with Portugal, Sweden and Ireland, this is one area where the UK has performed well (Table 2).

\section{Austerity}

Since 2010, governments have sought to slow public spending growth to reduce the public sector deficit which was $10.3 \%$ of GDP in 2009/10. ${ }^{23}$ While spending on the NHS has not reduced, in England the annual growth in public spending since 2010 has been much lower than in the past (Table 3 ).
Social care was not protected from austerity and between 2009/10 and 2016/17, social care spending in England fell by $13 \%$ per capita in real terms. ${ }^{24}$

Since the recession and consequential period of austerity the divergence between health spending and other public spending has been particularly marked. As Fig 4 shows that while health

Table 3. Annual average real growth rates in UK public spending on health, selected periods

\begin{tabular}{|c|c|c|}
\hline Period & $\begin{array}{l}\text { Financial } \\
\text { years }\end{array}$ & $\begin{array}{l}\text { Average annual real } \\
\text { growth rate }\end{array}$ \\
\hline Whole period & $\begin{array}{l}1949 / 50 \text { to } \\
2016 / 17\end{array}$ & $3.7 \%$ \\
\hline $\begin{array}{l}\text { Pre-1979 (various } \\
\text { governments) }\end{array}$ & $\begin{array}{l}1949 / 50 \text { to } \\
1978 / 79\end{array}$ & $3.5 \%$ \\
\hline $\begin{array}{l}\text { Thatcher and } \\
\text { Major Conservative } \\
\text { governments }\end{array}$ & $\begin{array}{l}1978 / 79 \text { to } \\
1996 / 97\end{array}$ & $3.3 \%$ \\
\hline $\begin{array}{l}\text { Blair and Brown Labour } \\
\text { governments }\end{array}$ & $\begin{array}{l}1996 / 97 \text { to } \\
2009 / 10\end{array}$ & $6.0 \%$ \\
\hline Coalition government & $\begin{array}{l}2009 / 10 \text { to } \\
2014 / 15\end{array}$ & $1.1 \%$ \\
\hline $\begin{array}{l}\text { Cameron and } \\
\text { May Conservative } \\
\text { governments }\end{array}$ & $\begin{array}{l}2014 / 15 \text { to } \\
2016 / 17\end{array}$ & $2.3 \%$ \\
\hline
\end{tabular}




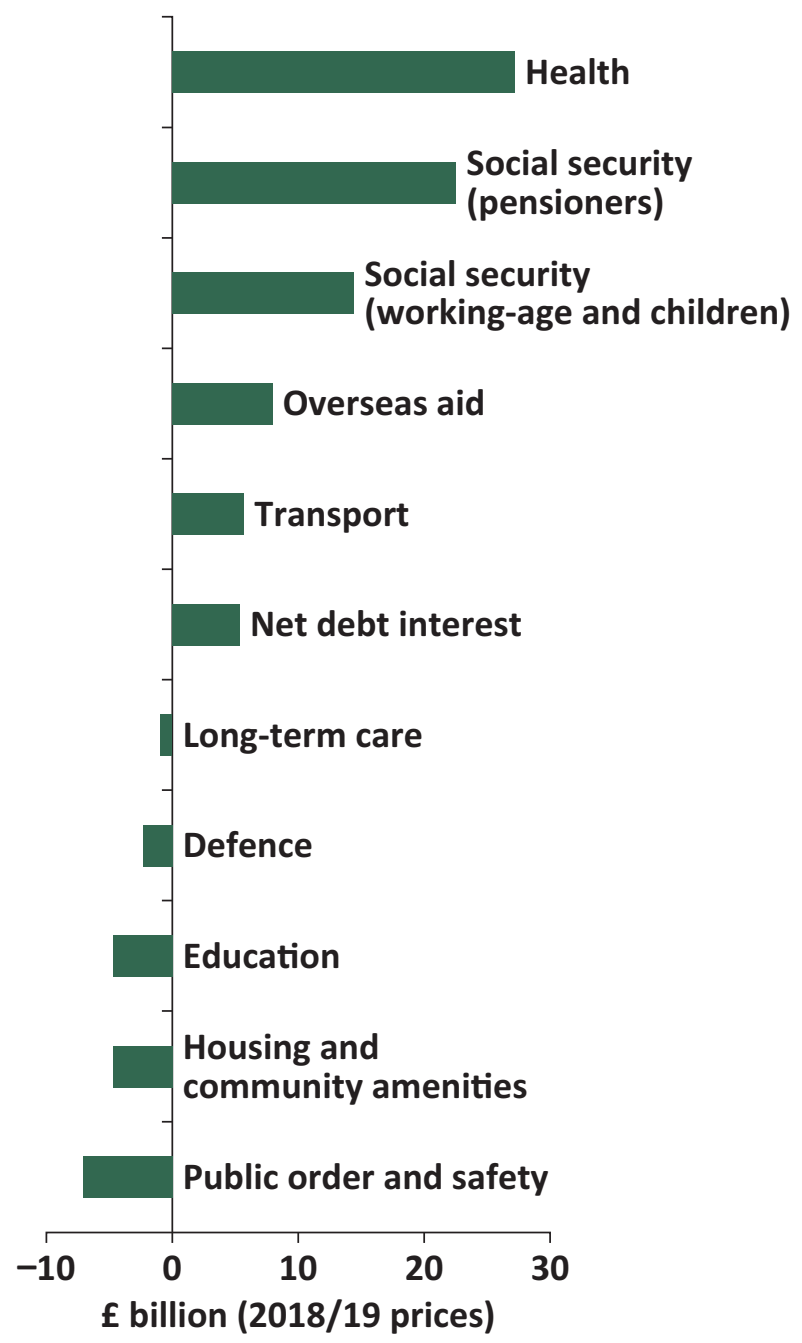

Fig 4. Real-terms absolute change in spending by function, 2007/08 to 2016/17

spending increased by $22.5 \%$ between $2007 / 08$ and 2016/17 ( $£ 27$ billion real terms increase), spending on other areas such as long-term care, education and housing fell.

Despite NHS productivity growth of $1.7 \%$ since $2009 / 10$, spending growth since 2010 has not kept pace with demand and cost pressures. The Health Foundation and Institute for Fiscal Studies (IFS) estimate that, in the next 15 years, real terms funding will need to grow by $3.3 \%$ in order to maintain current levels of service given the increasing and ageing population, rising patterns of chronic disease and realistic assessments of real wage growth and productivity. ${ }^{5}$ In June 2018 , the government committed to increase funding by $3.4 \%$ a year in real terms between 2019/20 and 2023/24; broadly in line with the estimate of the minimum funding growth required to sustain access and quality of care. ${ }^{25}$

This leaves little additional funds to improve care and invest in improving access in areas, such as mental health, when there is evidence of significant unmet need. ${ }^{26}$ The Health Foundation and IFS projections estimated that a modest programme of improvements and modernisation of NHS care would require funding growth of around $4.1 \%$ a year over the next 15 years to 2033/34

The NHS Long Term Plan does not contain any provision or promise of funding for social care in England. ${ }^{25}$ While funding for social care has grown, the guarantees are only to $2019 / 20 .^{27}$ This lack of a long-term plan reflects anticipation of the ever delayed social care green paper, originally promised in early summer 2018. Projections of social care demand estimate that, merely to keep up with demand pressures, funding for social care needs to grow by $3.7 \%$ per year to $2020 / 31 .{ }^{3}$ Funding growth has been consistently below this level since 2009/10 and as a result, the social care system is under immense pressure.

\section{The value of healthcare spending}

Healthcare spending growth on this scale inevitably raises questions about the 'value' of spending and its opportunity cost. As almost $80 \%$ of health spending in the UK is tax funded, increasing funding pressures have a significant impact on public finances. Health spending has grown at a much faster rate than total public spending, with other areas of public spending falling. Therefore, it now accounts for almost $£ 1$ in every $£ 5$ of all government spending. ${ }^{5}$ Health spending increased from 23 to $29 \%$ of public service spending between 2000 and 2010. By 2023 it is projected to account for $38 \%{ }^{28}$

Governments will therefore be concerned with ensuring that extra spending provides value for money.

The question of wider public spending is very important given that population health is substantially influenced by factors outside the provision of healthcare. McKeown decomposed the contribution of different factors to improving all cause-specific mortality for the century ending in $1971 .{ }^{29}$ Life expectancy had increased by 23 years during the first half century, but no more than a year or two was attributed to advances in medical care.

His conclusion that medical care had contributed little to health improvements didn't hold for the latter part of the 20th century in which medical care made a substantial contribution to gains in life expectancy: 'Three of the 7 years' increase in life expectancy since 1950 can be attributed to medical care. Medical care is also estimated to provide, on average, 5 years of partial or complete relief from the poor quality of life associated with chronic disease. $^{30}$

Average improvements in health are important but the NHS also has an explicit duty to reduce inequalities in health. ${ }^{31}$ Life expectancy and healthy life expectancy have a sharp social economic gradient in the UK and Marmot et al show that these are substantially driven by differences in the socio-economic determinants of health. ${ }^{32}$ Seventy years of a healthcare system which is based on need and not ability to pay and in which funding has been allocated to different communities based on relative need, has not been sufficient to reduce significantly these inequalities. $^{33}$

Research has examined the contribution of different factors to health gain from 1995 to 2005 across 35 countries, including the UK. It concludes that gains in life expectancy reflected factors both within and beyond the healthcare system. ${ }^{34} \mathrm{~A} 10 \%$ increase in health spending is associated with a gain of 3.5 months of life expectancy from 1995 to 2015. The same rate of improvement in healthier lifestyles - not smoking and decreased alcohol use is associated with a gain of 2.6 months of life expectancy. But social determinants also matter. A $10 \%$ increase in income or education 
is associated with a gain of 2.2 and 3.2 months of life expectancy, respectively.

Recent research suggests that in England extra health spending is cost-effective. ${ }^{35-37}$ This research finds that the cost of producing an additional year of quality adjusted life (QALY) through the NHS over that period ranged from $£ 5,000$ and $£ 15,000$, below the National Institute for Health and Care Excellence cost per QALY threshold for new treatments of $£ 20,000$ to $£ 30,000$.

There is growing interest in the impact of health and healthcare spending on societal outcomes. Most specifically, does health and healthcare contribute to economic performance? Greater capacity to work and higher productivity when in work contribute to increased tax revenues and lower spending on health-related social security payments, benefiting public finances as well as a link between health status, participation in the labour market (including through later retirement) and earnings. ${ }^{38,39}$ Economic growth can also be influenced by the health of those who do not participate in the formal labour market, such as children, older people or those who are care dependent. ${ }^{38}$ Children in ill health may be less able to attend school regularly and older adults in ill health may be unwilling or unable to invest in their human capital if they believe that their productive life expectancy is likely to be cut short by illness or death. ${ }^{40}$

The health and care system is a large sector of the economy ( $10 \%$ of GDP) and a major source of employment, employing $12 \%$ of workers in the UK. However, the debate on how the health sector affects economy-wide productivity is unresolved. There is increasing interest in the role of the health system as trainer, employer and purchaser of goods and service in economic growth. The evidence for the link between these functions and macroeconomic growth is limited and this should be a priority for further research. ${ }^{11}$

The evidence of the marginal cost-effectiveness of different choices for public spending is much more limited. Research on public health interventions suggests that they are often highly cost effective and offer a high rate of return. ${ }^{41}$ Spending on public health has fallen in recent years from $£ 2.9$ billion in 2014/15 to $£ 2.6$ billion in $2017 / 18$, when accounting for changes to the range of services provided from 2014/15 to 2019/20 there will have been a $25 \%$ real term per capita cut in spend. This, in contrast to spending on the wider health budget, means spending on public health is $2.0 \%$ of the total Department of Health and Social Care budget in $2017 / 18$, compared to $2.4 \%$ in $2014 / 15$.

\section{Conclusion}

Publicly funded health and social care now account for almost $£ 1$ in $£ 10$ of the UK's national income. The pressure to increase funding is not reducing. Over the medium-term, demand and cost drivers will continue to increase at a much faster rate than inflation or economic growth. This will raise important questions about the value of additional spending and its impact on wider society. There are clear challenges for the NHS; to ensure that spending is productive and extra investment is directed to areas which offer significant potential improvements in mortality and morbidity. But, beyond this, there are important questions on which evidence and research are still limited on whether the NHS and care pound can be used to support wider societal objectives for economic growth and opportunities. Also, if the objective is to improve health, should the health service be the first call for any additional public funding?

\section{References}

1 Public Health England. Chapter 1: life expectancy and healthy life expectancy. In: Health profile for England: 2017. PHE, 2017. www.gov.uk/government/publications/health-profile-for-england/ chapter-1-life-expectancy-and-healthy-life-expectancy\#life-expectancy-and-healthy-life-expectancy-at-birth [Accessed 01 February 2019].

2 Health Education England. Health Education England strategic framework: 2014-2029. HEE, 2017. www.hee.nhs.uk/sites/default/ files/documents/HEEstrategic framework 2017_1.pdf [Accessed 01 February 2019].

3 Watt TLS, Varrow M, Charlesworth A, Roberts A. Social care funding options: How much and where from? London: The Health Foundation, 2018. www.health.org.uk/publications/social-carefunding-options.

4 Watt TLS. The 'do nothing' option: How public spending on social care in England fell by $13 \%$ in 5 years. London: The Health Foundation, 2018. www.health.org.uk/blogs/the-'do-nothing'option-how-public-spending-on-social-care-in-england-fell-by-13-infive-years [Accessed 31 January 2019].

5 Charlesworth A, Johnson P (eds). Securing the future: funding health and social care to the 2030s. London: The Institute for Fiscal Studies, 2018. www.ifs.org.uk/uploads/R143.pdf.

6 Office for Budget Responsibility. Fiscal sustainability report January 2017. London: Office for Budget Responsibility, 2017. http://obr.uk/fsr/fiscal-sustainability-report-january-2017.

7 Luchinskaya D, Simpson P, Stoye G. UK health and social care spending. In: Emmerson C, Johnson P, Joyce R (eds). The IFS Green Budget. London: The Institute for Fiscal Studies, 2017.

8 World Health Organization. Global status report on noncommunicable diseases 2014. Geneva: WHO, 2014.

9 Stafford M, Steventon A, Thorlby R et al. Briefing: Understanding the healthcare needs of people with multiple health conditions. London: The Health Foundation, 2018. www.health.org.uk/sites/ default/files/upload/publications/2018/Understanding the healthcare needs of people with multiple health conditions.pdf [Accessed 01 February 2019].

10 Getzen TE. Healthcare is an individual necessity and a national luxury: Applying multilevel decision models to the analysis of healthcare expenditures. J Health Econ 2000;19:259-70.

11 de la Maisonneuve C, Martins JO. Public spending on health and long-term care: a new set of projections. OECD Economic Policy Papers 2013;6.

12 Roberts A, Marshall L, Charlesworth A. A decade of austerity? The funding pressures facing the NHS from 2010/11 to 2021/22. Research report. London: Nuffield Trust, 2012.

13 Baumol W]. Healthcare, education and the cost disease: A looming crisis for public choice. Public Choice 1993;77:17-28.

14 Office for National Statistics. Public service productivity: healthcare, England: financial year ending 2017. ONS, 2019. www.ons.gov. uk/economy/economicoutputandproductivity/publicservicesproductivity/articles/publicservicesproductivityestimateshealthcare/ financialyearending2017 [Accessed 01 February 2019].

15 Buchan J, Seccombe I, Gershlick B, Charlesworth A. In short supply: Pay policy and nurse numbers: Workforce profile and trends in the English NHS. London: The Health Foundation, 2017. www.health.org.uk/publications/in-short-supply-pay-policy-andnurse-numbers.

16 The World Bank. Out-of-pocket expenditure (\% of current health expenditure). Washington: The World Bank, 2015. https:// data.worldbank.org/indicator/SH.XPD.OOPC.CH.ZS?year_high_ desc $=$ false [Accessed 01 February 2019]. 
17 The World Bank, World Health Organization. Tracking universal health coverage: 2017 global monitoring report. Geneva: WHO and International Bank for Reconstruction and Development / The World Bank, 2017. http://documents.worldbank.org/curated/ en/640121513095868125/pdf/122029-WP-REVISED-PUBLIC.pdf [Accessed 01 February 2019].

18 Appleby J, Gershlick B. Keeping up with the Johanssons: How does UK health spending compare internationally? BMJ 2017;358:j3568.

19 Wagstaff A. Social health insurance vs tax-financed health systems-evidence from the OECD. Washington: The World Bank, 2009. http://documents.worldbank.org/curated/ en/545121468028868365/Social-health-insurance-vs-taxfinanced-health-systems-evidence-from-the-OECD [Accessed 01 February 2019].

20 Wagstaff A. Social health insurance reexamined. Washington: The World Bank, 2007.

21 Organisation for Economic Co-operation and Development. Health reform: Meeting the challenge of ageing and multiple morbidities. Paris: OECD, 2011.

22 Srivastava D, Mueller M, Hewlett E. Better ways to pay for health care. Paris: OECD, 2016.

23 Office for National Statistics. UK government debt and deficit: September 2016. ONS, 2017. www.ons.gov.uk/economy/governmentpublicsectorandtaxes/publicspending/bulletins/ukgovernmentdebtanddeficitforeurostatmaast/julytosept2016 [Accessed 31 January 2019].

24 HM Treasury. Public expenditure: Statistical analyses 2018. London: HM Treasury, 2018. https://assets.publishing.service. gov.uk/government/uploads/system/uploads/attachment_data/ file/726878/PESA_2018_Print.pdf [Accessed 01 February 2019].

25 NHS. NHS Long Term Plan. NHS, 2019. www.longtermplan.nhs.uk/ publication/nhs-long-term-plan.

26 Charlesworth A. Running to stand still. Health Serv J 2018. www.hsj. co.uk/finance-and-efficiency/running-to-stand-still/7023170.article. [Accessed 31 January 2019].

27 HM Treasury, Hammond P. Budget 2018: Philip Hammond's speech. HM Treasury, 2018.

28 Johnson P. Autumn budget 2018: IFS analysis: Paul Johnson's opening remarks. IFS, 2018. www.ifs.org.uk/uploads/budgets/ budget2018/pj_budget2018.pdf [Accessed 01 February 2019].
29 McKeown T. The role of medicine: Dream, mirage, or nemesis? London: Nuffield Provincial Hospitals Trust, 1976.

30 Bunker JP. Medicine matters after all. J R Coll Physicians Lond 1995:29:105-12.

31 UK government. Health and social care act 2012. Norwich: The Stationery Office, 2012.

32 Marmot M, Bell R. Fair society, healthy lives. Public Health 2012;126(Suppl 1):S4-10.

33 Office for National Statistics. Health state life expectancies, UK: 2015 to 2017. ONS, 2018.

34 James C, Devaux M, Sassi F. Inclusive growth and health. Paris: OECD, 2017.

35 Claxton KP, Lomas JRS, Martin S. The impact of NHS expenditure on health outcomes in England: Alternative approaches to identification in all-cause and disease specific models of mortality. Health Econ 2018;27:1017-23.

36 Lomas JRS, Martin S, Claxton KP. Estimating the marginal productivity of the English National Health Service from 2003/04 to 2012/13. York: Centre for Health Economics, 2018.

37 Nakamura R, Lomas JRS, Claxton KP et al. Assessing the impact of health care expenditures on mortality using cross-country data. York: Centre for Health Economics, 2016.

38 Cylus J, Permanand G, Smith PC. Making the economic case for investing in health systems. Copenhagen: World Health Organization, 2018.

39 Johnson P, Stoye G, Sturrock D. Health and economic outcomes. In: Davies SC. Annual Report of the Chief Medical Officer, 2018: Health 2040 - better health within reach. Department of Health and Social Care, 2018

40 Dayan M, Ward D, Gardner T, Kelly E. NHS at 70: How good is the NHS? London: The Health Foundation, The Institute for Fiscal Studies, The King's Fund and the Nuffield Trust, 2018.

41 Masters R, Anwar E, Collins B, Cookson R, Capewell S. Return on investment of public health interventions: A systematic review. J Epidemiol Community Health 2017;71:827-34.

Address for correspondence: Toby Watt, senior economist, The Health Foundation, 90 Long Acre, London WC2E 9RA. Email: toby.watt@health.org.uk 